\title{
Effect of Wrapping Reinforced Concrete Surface with FRP Sheets on Corrosion Resistance
}

\author{
Mohamed R. Masoud, Ahmed M. Ebid
}

\begin{abstract}
Fiber Reinforced Plastics (FRP) sheets are widely used now in the field of repair and strengthening of reinforced concrete structures. The presence of FRP sheets on reinforced concrete surface for repair and strengthening provides some level of protection for reinforced concrete against corrosion. This kind of protection can be considered as an indirect protection because the main purpose is not for protection but for repair and strengthening. Two fibers/resin systems were considered in the experimental program; the first is glass/polyester system with one, two, and three layers of glass fibers and the second is carbon/polyester system with one layer of carbon fibers. Effectiveness of the indirect method was evaluated through comparing them with the well-known direct protection methods (coating of steel surface, coating of concrete surface, and by using concrete admixtures). A total of 16 accelerated corrosion cells were tested in order to measure the total mass loss of the reinforcing steel bars which expresses the effectiveness of all direct and indirect protection methods.
\end{abstract}

Keywords: Corrosion resistance; (FRP) wrapping sheets; indirect corrosion protection; CFRP; GFRP.

\section{INTRODUCTION}

Externally bonded FRP on the surface of different RC elements is a well-known technique used for repair and strengthening purposes. High tensile strength, high strength to weight ratio, high corrosion resistance, better fatigue behavior, high durability, and the possibility of tailoring the required mechanical properties in any direction are the major advantages of using this technique compared to other traditional techniques of repair and strengthening. Generally FRP's offer unique advantages for solving many civil engineering problems in areas where conventional materials fail to provide satisfactory performance $[1,8]$. Unlike steel, FRP's are unaffected by electrochemical deterioration and can resist the corrosive effects of acids, alkalis, salts, and similar aggressive materials. Presence of FRP sheets on the reinforced concrete surface will increase the protection level against corrosion of steel reinforcement [8]. Although this

Revised Manuscript Received on December 30, 2019.

* Correspondence Author

Mohamed R. Masoud*, Assistant Professor, Department of Structural Engineering, Faculty of Engineering, Ain Shams University, Cairo, Egypt. E-Mail : mohamed_abdelmagid@eng.asu.edu.eg

Ahmed M. Ebid*, Lecturer, Department of Structural Engineering, Faculty of Engineering \& Technology, Future University, Cairo, Egypt. E-Mail : ahmed.abdelkhaleq@fue.edu.eg

(C) The Authors. Published by Blue Eyes Intelligence Engineering and Sciences Publication (BEIESP). This is an open access article under the CC BY-NC-ND license (http://creativecommons.org/licenses/by-nc-nd/4.0/) protection method is not the main purpose of using FRP sheets, but it can be considered as an indirect protection method. Different techniques with variable effectiveness are used to protect steel reinforcement against corrosion. Choice of the most suitable protection method depends on many factors as cost, nature of the structure, and the required level of protection. Surface coatings of steel and concrete surfaces and concrete admixtures used reduce corrosion rate are considered the most widely used direct protection techniques used [2-6].

\section{OBJECTIVES}

The main objective of this research is to evaluate the effectiveness of using bonded FRP sheets to the RC surface as an indirect protection method against reinforcing steel corrosion. This evaluation will be done through comparing the corrosion resistance of reinforced concrete wrapped with FRP layers with non-protected concrete (as a control case) and with concrete protected with the well-known traditional protection methods (coating of steel surface, coating of concrete surface, and using concrete admixtures). Some parameters related to FRP will be considered such as the type of reinforcing fibers (glass and carbon fibers) and number of FRP layers (one, two, and three layers will be considered).

\section{MATERIALS AND TEST SPECIMENS}

\section{A. Concrete}

The used concrete has the following mix proportions for 1.0 $\mathrm{m}^{3}$ by weight:

- $375 \mathrm{~kg}$ of OPC of grade R 42.5

- $1070 \mathrm{~kg}$ of coarse aggregate (crushed stone)

- $655 \mathrm{~kg}$ of natural sand (fineness modulus of 2.30)

- 190 liter of water

Table-I shows the grain size analysis for both coarse and fine aggregates, while Table-II illustrate the physical properties of the used crushed stone and sand. The average achieved cube compressive strengths were 246 and $304 \mathrm{~kg} / \mathrm{cm}^{2}$ after 7 and 28 days respectively.

$12 \mathrm{~mm}$ diameter deformed bar of grade $36 / 52$ was placed in the center of each specimen. All the specimens were cured by wet burlap until the test date.

\section{B. FRP materials}

The used FRP materials were Glass fiber fabric strengthening system and Carbon fiber fabric strengthening system produced by Sika. The used matrix was Sikadur330. Table III gives all the properties taken from the technical data sheet given by Sika. 


\section{Protection materials}

As mentioned earlier, three well-known protection methods were used for comparison purposes. The first method is coating of steel surface by one layer of Euxit-ZNP. The second is coating of concrete surface by Addicor-M to isolate the concrete surface. The third is using Addicrete-DM2 as a chemical liquid admixture to decrease the concrete permeability. Handling of the three materials (Euxit-ZNP, Addicor-M, and Addicrete-DM2) was done according to the technical information given by the manufacturers.

Table-I: Grain size analysis of fine \& coarse aggregates

\begin{tabular}{|c|c|c|c|c|c|c|c|}
\hline $\begin{array}{c}\text { Fine } \\
\text { Aggregat } \\
\mathbf{e}\end{array}$ & $\begin{array}{c}\text { Sieve } \\
\text { size } \\
\mathbf{( m m )}\end{array}$ & 4.75 & 2.36 & 1.18 & 0.60 & 0.30 & 0.15 \\
\cline { 2 - 8 } & Pass \% & 99.5 & 98.8 & 73.1 & 61.3 & 32.0 & 7.0 \\
\hline $\begin{array}{c}\text { Coarse } \\
\text { Aggregat } \\
\mathbf{e}\end{array}$ & $\begin{array}{c}\text { Sieve } \\
\text { size } \\
\mathbf{( m m )}\end{array}$ & 37.5 & 31.5 & 28.0 & 20.0 & 10.0 & 5.0 \\
\cline { 2 - 8 } & Pass \% & 100 & 100 & 100 & 66.8 & 11.6 & 0.0 \\
\hline
\end{tabular}

Table-II: Properties of sand \& crushed stone

\begin{tabular}{|c|c|c|}
\hline Property & Sand & $\begin{array}{c}\text { Crushed } \\
\text { Stone }\end{array}$ \\
\hline Specific gravity & 2.48 & 2.50 \\
\hline Unit weight (t/m ${ }^{3}$ ) & 1.43 & 1.58 \\
\hline $\begin{array}{c}\text { Crushing value (Los } \\
\text { Anglos) \% }\end{array}$ & --- & 24.0 \\
\hline $\begin{array}{c}\text { fine materials (by volume) } \\
\%\end{array}$ & 4.0 & --- \\
\hline $\begin{array}{c}\text { Absorption } \\
\%\end{array}$ & --- & 2.2 \\
\hline
\end{tabular}

Table-III: Properties of FRP materials

\begin{tabular}{|c|c|c|}
\hline \multicolumn{3}{|c|}{ 1) Reinforcing Fibers } \\
\hline Property & E-Glass fibers & $\begin{array}{c}\text { Carbon } \\
\text { Fibers }\end{array}$ \\
\hline Fiber Orientation & $0^{\circ}$ & $0^{\circ}$ \\
\hline Weight / area & $430 \mathrm{~g} / \mathrm{m}^{2}$ & $225 \mathrm{~g} / \mathrm{m}^{2}$ \\
\hline Tensile strength & $2250 \mathrm{~N} / \mathrm{mm}^{2}$ & $3500 \mathrm{~N} / \mathrm{mm}^{2}$ \\
\hline E-modulus (in & $70000 \mathrm{~N} / \mathrm{mm}^{2}$ & 230000 \\
tension) & $3.1 \%$ & $1.5 \%$ \\
\hline Failure strain & 2) Binding Matrix \\
\hline \multicolumn{2}{|c|}{$1.31 \mathrm{~g} / \mathrm{cm}^{3}$} \\
\hline Density & $30 \mathrm{~N} / \mathrm{mm}^{2}$ \\
\hline Tensile strength & $3800 \mathrm{~N} / \mathrm{mm}^{2}$ \\
\hline Flexural modulus & Pasty not flowable \\
\hline Viscosity &
\end{tabular}

\section{EXPERIMENTAL PROGRAM}

16 specimens were tested in this study with two main protection methods. Each specimen was tested using a separate accelerated corrosion cell and the corrosion current was measured every 2 hours for a period of 200 hours. These two main protection methods are:

\section{A. Direct Protection}

Six specimens were tested using direct or well-known protection methods; these methods are:

- Coating of steel surface: Two specimens designated as (SC) were protected by coating of the steel surface with one layer of Euxit-ZNP.

- Coating of concrete surface: Two specimens designated as (CC) were protected by coating of concrete surface with Addicor-M.

- Concrete admixture: Two specimens designated as (CA) were protected by using a concrete admixture. This type of admixture used to decrease the permeability of concrete and to increase its chemical resistance as given by the manufacturer in the technical information sheet.

\section{B. Indirect Protection:}

Eight specimens were tested using FRP wrapping as indirect protection:

- Wrapping with one layer of glass fibers: Two specimens designated as (G1) were wrapped with one layer of glass fibers and Sikadur330 matrix.

- Wrapping with two layers of glass fibers: Two specimens designated as (G2) were wrapped with two layers of glass fibers and Sikadur330 matrix.

- Wrapping with three layers of glass fibers: Two specimens designated as (G3) were wrapped with three layers of glass fibers and Sikadur330 matrix.

- Wrapping with one layer of carbon fibers: Two specimens designated as (C1) were wrapped with one layer of carbon fibers and Sikadur330 matrix.

It has to be noted that there are two specimens without any protection used as control specimens. These two specimens were designated as (NP). Table-IV gives the details for the test specimens, used protection method and the identification for each specimen individually.

Table- IV: Details of experimental program

\begin{tabular}{|c|c|c|c|}
\hline $\begin{array}{c}\text { Protection } \\
\text { Method }\end{array}$ & Details & $\begin{array}{c}\text { No. of } \\
\text { Specime } \\
\text { ns }\end{array}$ & $\begin{array}{c}\text { Cod } \\
\mathbf{e}\end{array}$ \\
\hline $\begin{array}{c}\text { No Protection } \\
\text { (Control case) }\end{array}$ & No Protection & 2 & $\mathrm{NP}$ \\
\hline \multirow{4}{*}{$\begin{array}{c}\text { Indirect } \\
\text { Protection }\end{array}$} & 1 layer GFRP & 2 & $\mathrm{G} 1$ \\
\cline { 2 - 4 } & 2 layer GFRP & 2 & $\mathrm{G} 2$ \\
\cline { 2 - 4 } & 3 layer GFRP & 2 & $\mathrm{G} 3$ \\
\cline { 2 - 4 } & 1 layer CFRP & 2 & $\mathrm{C} 1$ \\
\hline \multirow{3}{*}{$\begin{array}{c}\text { Direct } \\
\text { protection }\end{array}$} & $\begin{array}{c}\text { Steel Coating } \\
\text { Concrete }\end{array}$ & 2 & $\mathrm{SC}$ \\
\cline { 2 - 4 } & $\begin{array}{c}\text { Concrete } \\
\text { Admixture }\end{array}$ & 2 & $\mathrm{CC}$ \\
\hline
\end{tabular}

All tested specimens were lollypop specimens with $100 \mathrm{~mm}$ diameter and $200 \mathrm{~mm}$ length. Each specimen had an embedded $10 \mathrm{~mm}$ diameter steel bar in its center with embedded and total lengths of $130 \& 300 \mathrm{~mm}$ respectively to ensure that concrete cover is more than $45 \mathrm{~mm}$. All specimens were immersed in a $15 \%$ Sodium chloride $(\mathrm{NaCl})$ solution at the room temperature and surrounded by steel pipes which were cleaned regularly to prevent depositing of salt on their surfaces.

Published By:

Blue Eyes Intelligence Engineering \& Sciences Publication

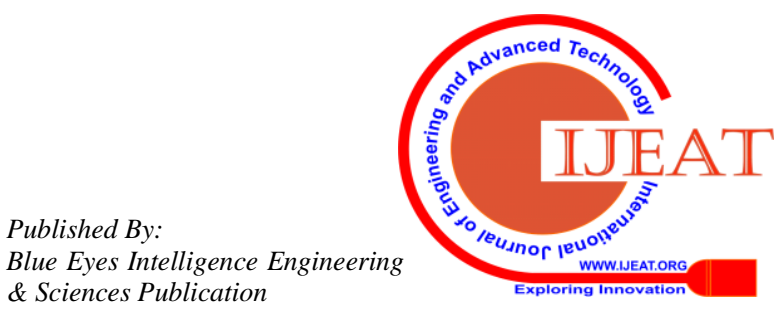




\section{TEST PROCEDURE AND RESULTS}

All lollypops specimens were tested using the accelerated corrosion test (galvano-static method). The test setup allows an impressed current to flow the central steel bar by applying a potential difference of 15 volt across the steel bar (anode) and a steel pipe round the specimen (cathode) [2, $7 \&$ 9].

A fixed resistance of $100 \mathrm{Ohm}$ connected in series was used to measure the impressed current by recording the potential difference between its connectors and divided it by the resistance value. During the test, the measured current was recorded each two hours for 200 hours. Fig. 1 shows the layout of the accelerated corrosion test setup.

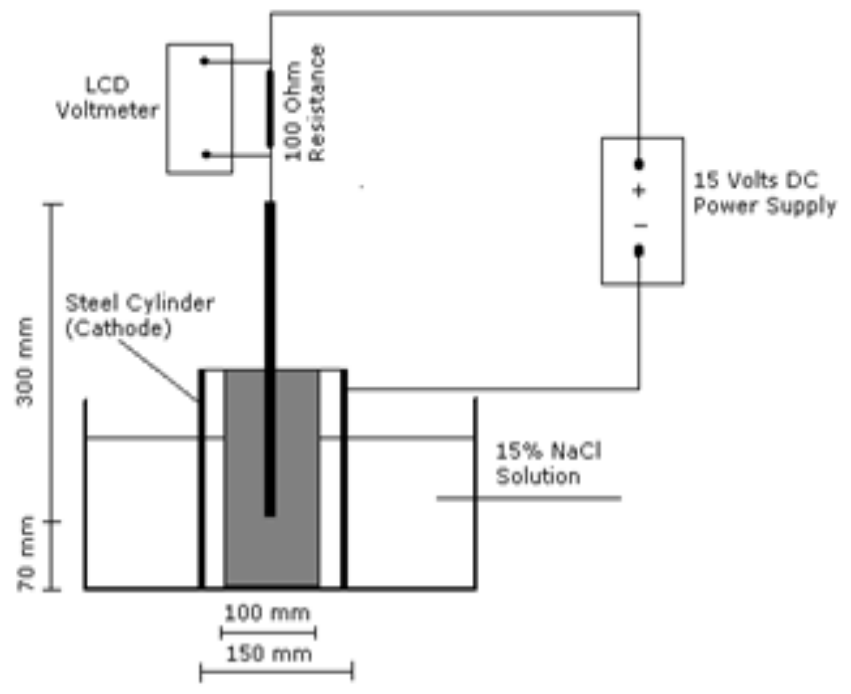

Fig. 1.Accelerated Corrosion Test Setup

The recorded current values were plotted aginst time to claculate the area below this curve. Then the total mass loss was calculated from the area below the curve using Faraday's equation as follows:

Total mass loss $(\mathrm{gm})=[\mathrm{M} /(\mathrm{Z} * \mathrm{~F})][\mathrm{A}]$

Where: $\mathrm{A}=\left[\int \mathrm{I}\right.$.dt $]$

(electrical charge)

$\mathrm{M}=55.85 \mathrm{gm} / \mathrm{mol}$

(atomic weight of iron).

$\mathrm{Z}=2$ (ionic charge iron).

$\mathrm{F}=96485.3 \mathrm{C} / \mathrm{mole}$ of $\mathrm{e}^{-}$(Faraday's constant)

Fig. 2 shows the time - corrosion current relationship for NP and G3 specimens. Table- $\mathrm{V}$ gives the calculated total mass loss (Mt) for all the test specimens.

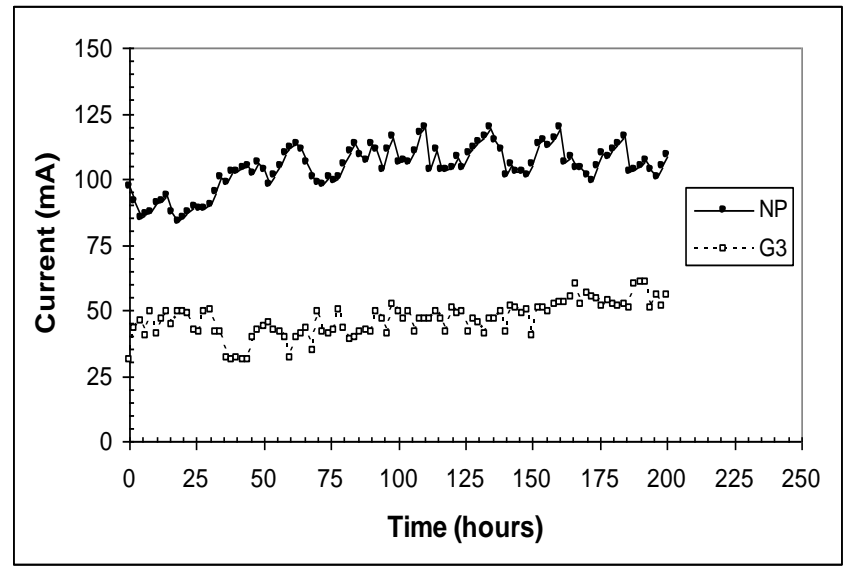

Fig. 2.Time-Current relationship for NP and G3 specimens
Table-V: Total Mass Loss for Test Specimens

\begin{tabular}{|c|c|c|c|c|}
\hline $\begin{array}{c}\text { Protection } \\
\text { Method }\end{array}$ & Spec. & $\begin{array}{l}\text { Mass } \\
\text { Loss } \\
(\mathrm{gm})\end{array}$ & $\begin{array}{c}\text { Av. } \\
\text { Mass } \\
\text { loss } \\
\text { (gm) }\end{array}$ & $\begin{array}{l}\text { \% from } \\
\text { control }\end{array}$ \\
\hline \multirow{2}{*}{ Control } & NP & 21.7 & \multirow{2}{*}{22.30} & \multirow{2}{*}{100} \\
\hline & NP & 22.9 & & \\
\hline \multirow{8}{*}{$\begin{array}{c}\text { Indirect } \\
\text { Protection }\end{array}$} & G1 & 18.11 & \multirow{2}{*}{18.17} & \multirow{2}{*}{81.5} \\
\hline & G1 & 18.22 & & \\
\hline & G2 & 11.17 & \multirow{2}{*}{11.60} & \multirow{2}{*}{52.0} \\
\hline & G2 & 12.02 & & \\
\hline & G3 & 9.61 & \multirow{2}{*}{9.52} & \multirow{2}{*}{42.7} \\
\hline & G3 & 9.42 & & \\
\hline & C1 & 18.56 & \multirow{2}{*}{18.65} & \multirow{2}{*}{83.6} \\
\hline & $\mathrm{C} 1$ & 18.73 & & \\
\hline \multirow{6}{*}{$\begin{array}{c}\text { Direct } \\
\text { Protection }\end{array}$} & SC & 3.27 & \multirow{2}{*}{3.19} & \multirow{2}{*}{14.3} \\
\hline & SC & 3.11 & & \\
\hline & $\mathrm{CC}$ & 18.17 & \multirow{2}{*}{18.25} & \multirow{2}{*}{81.8} \\
\hline & $\mathrm{CC}$ & 18.32 & & \\
\hline & CA & 16.50 & \multirow{2}{*}{16.80} & \multirow{2}{*}{75.3} \\
\hline & CA & 17.10 & & \\
\hline
\end{tabular}

\section{DISCUSSION}

- Fig.3 shows the average mass loss for specimens wrapped with glass and carbon FRP. The average mass losses for these specimens were $81.5 \%$ and $83.6 \%$ from that of control specimen respectively. These results show that the type of reinforcing fibers has no significant effect on the corrosion resistance of reinforced concrete. Also the results imply that the bonding material thickness is the key issue for providing a certain level of protection.

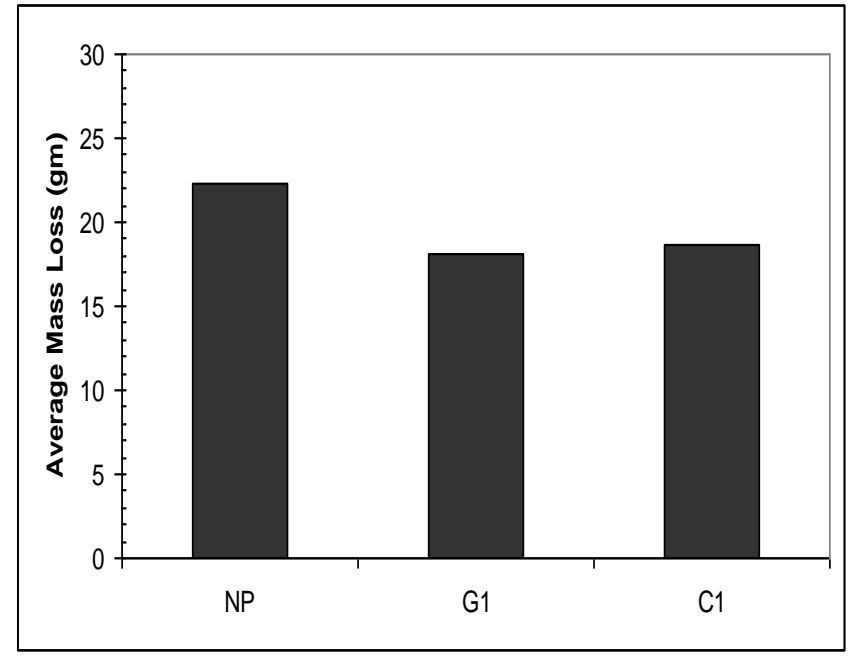

Fig. 3.Average mass loss (gm) for different types of reinforcing fibers

- Fig.4 shows the average mass loss in grams for three wrapped specimens with different number of glass FRP layers (one, two, and three layers). From that figure, it can be shown that the average mass loss for one, two, and three layers are $81.50 \%, 52.00 \%$, and $42.7 \%$ from the control case respectively. 
Based on this result, it can be noted that the number of FRP layers has a remarkable effect on the corrosion resistance of reinforced concrete. This may be related to the increase in the bonding material layers (i.e. thickness). This result strengthens the aforementioned one in the previous discussed point.

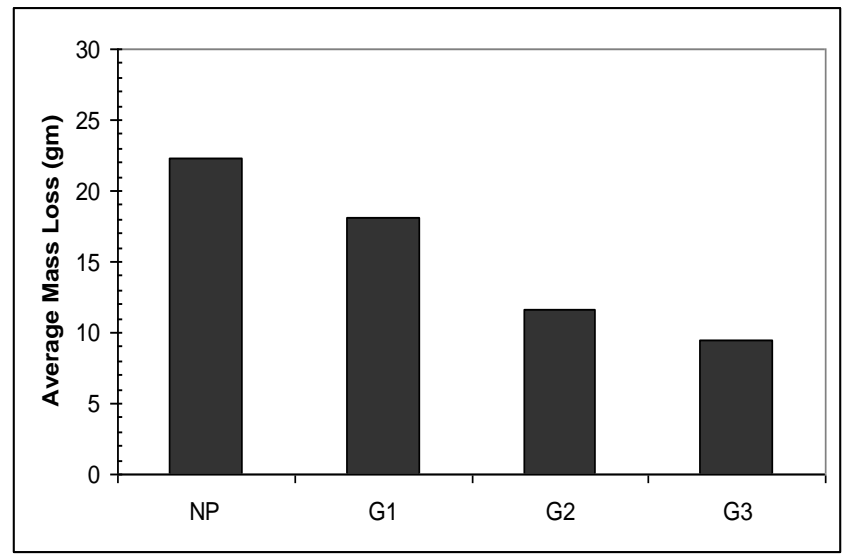

Fig. 4.Average mass loss (gm) for different numbers of GFRP layers

- For the well-known direct protection methods used in this study, as shown from Fig.5, the average mass loss for the cases of steel coating, concrete coating and concrete admixture are $14.3 \%, 81.8 \%$, and $75.3 \%$ from the control case respectively. This means that the most effective direct protection method is the steel coating. Using of concrete coating or concrete admixtures has very limited effectiveness compared to the case of steel coating.

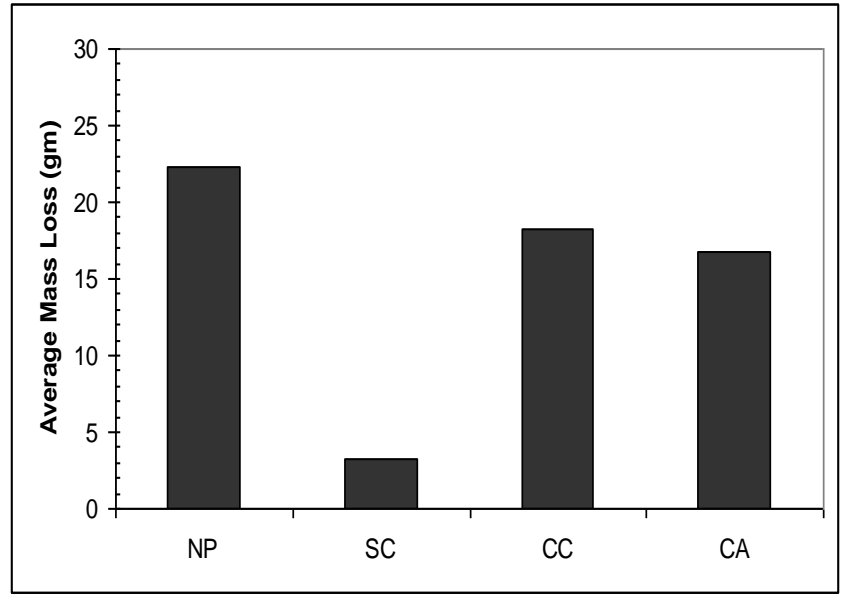

Fig. 5.Average mass loss (gm) for direct protection methods

- Comparing the steel coating method (as the best direct protection method) with wrapping the concrete surface with three layers of GFRP (as the best indirect protection method), figure 6 shows that the average mass loss for the first case is $14.3 \%$ and $42.7 \%$ for the second case. This result shows that by using wrapping, it was still far from the protection level provided by steel coating but it is quite good because wrapping was used mainly for repair and strengthening purposes and not for protection. So reducing the average mass loss by about $57 \%$ from the control case is considered well enough in this case.

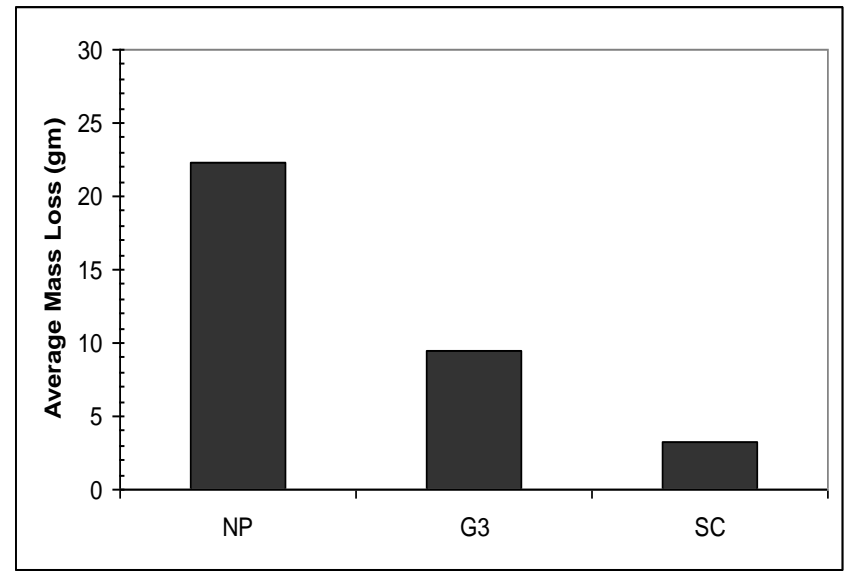

Fig. 6.Average mass loss (gm) for the best direct and indirect protection methods

\section{CONCLUSIONS}

Based on the discussion of the obtained test results, the following points can be easily concluded:

1. Type of reinforcing fibers has no significant effect on the corrosion resistance of reinforced concrete. Glass and Carbon fibers gives almost the same protection level.

2. Thickness of bonding material layers has the major effect on the corrosion resistance of reinforced concrete. Three layers of polyester provide higher protection level than two layers. Similarly, two layers of polyester provide higher protection level than one layer.

3. The best direct protection method is the coating of reinforcing steel surface. Steel coating is more effective in corrosion resistance than both concrete coating and concrete admixtures.

4. Steel coating is more effective in protection against corrosion than the used three layers of GFRP. But the protection level provided by the three layers is considered satisfactory.

\section{REFERENCES}

1. Ballinger C.A. "Advanced Composites in the Construction Industry" Proceedings from the 37th. International SAMPE symposium, March 1992.

2. Elesener, et al, (2003). "Half-cell potential measurements- potential mapping on Reinforced Concrete structural", Mat. Struct. 36-461-471.

3. Goyal, Arpit, et al., (2018), "A Review of Corrosion and Protection of Steel in Concrete", Arabian Journal for Science and Engineering (2018): 1-21.

4. Goyal, Arpit, et al., (2019), "Predicting the corrosion rate of steel in cathodically protected concrete using potential shift.", Construction and Building Materials 194 (2019): 344-349.

5. Hansson, Jaffer et al., (2007), "Corrosion of reinforcing bars in concrete", Portland cement Association, Skokie, Illinois, USA.

6. Ha-won song, (2007), "Corrosion monitoring of reinforced concrete structures-A Review”, International Journal of electrochemical science 2, 1-28.

7. Muazzam Ghous, (2013), "Corrosion of steel in concrete: development of an accelerated test by carbonation and galvanic coupling", $\mathrm{PhD}$. Thesis, De Toulouse university.

8. Nanni A. "Fiber Reinforced Plastic materials" Proceedings from the first middle-east workshop on structural composites, Sharm El-Shiekh, Egypt, June 1996, pp. 1-24.

9. R.Baboian, (1995), "Corrosion test and standards: application and interpretation”, Philadelphia, pa: ASTM. 


\section{AUTHORS PROFILE}

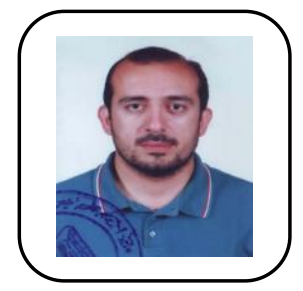

Mohamed R. Masoud was graduated from Structural Engineering department, Faculty of Engineering, Ain Shams University, Cairo, Egypt in June1991. He got his M.Sc. and Ph.D. from the same department in 1998 and 2007 respectively. Now he works as an Assistant Professor in the same department. His scientific research interest is in the field of performance and durability of concrete, corrosion of steel reinforcement, and repair and strengthening of RC structures. In addition He is a professional engineer in the Egyptian general organization of educational buildings. He works in the field of repair and strengthening of such buildings.

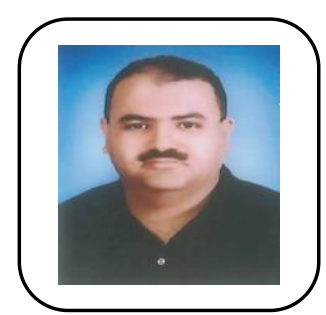

Ahmed M. Ebid was graduated from Structural Engineering department, Faculty of Engineering, Ain Shams University, Cairo, Egypt in June1996. He got his M.Sc. and Ph.D. from the same department in 2001 and 2004 respectively. Presently, he is a lecturer in structural department, faculty of engineering, Future University in Egypt. His scientific research interests are in geotechnical engineering, concrete structures, applications of (AI) in structural engineering. He published 16 researches in geotechnical engineering, repairing using FRP, optimization of concrete structures \& applications of (GP) in structural engineering. He is a consultant in Geotechnical engineering \& Concrete structures since 2012. 